\title{
Intramural coronary arterial course
}

INSERM

\section{Source}

INSERM. (1999). Orphanet: an online rare disease and orphan drug data base. Intramural coronary arterial course. ORPHA:99088

Intramural coronary arterial course is a rare coronary artery cong enital malformation disorder characterized by an atypical course of a coronary artery (usually proximal left anterior descending artery) in which, for a variable length, the artery runs intramyocardally. Depending on the artery and length of segment involved, patients may be asymptomatic or may present variable manifestations ranging from atypical angina to sudden death. 